\title{
HUBUNGAN ANTARA SEDIMEN DENGAN LOGAM BERAT DAN MAKROZOOBENTOS DI SUNGAI SIANGKER, SEMARANG
}

Corelation between Sedimentwith Heavy Metals and Macrozoobenthosin Siangker River, Semarang.

\section{Arini Indah Lestari, Mustofa Niti Supardjo, Boedi Hendrarto}

Program StudiManajemenSumberdayaPerairan, Departemen Sumberdaya Akuatik

FakultasPerikanandanIlmuKelautan, UniversitasDiponegoro

Jl. Prof. Soedarto, SH, Tembalang, Semarang, Jawa Tengah - 50275, Telp/Fax. +6224 7474698

Email : ariiniindah.21@gmail.com

\begin{abstract}
ABSTRAK
Sungai Siangker merupakan salah satu sub sistem dari sistem drainase Semarang Barat yang mengalami pendangkalan.Limbah yang berasal dari pabrik diduga mengandung logam berat $\mathrm{Pb}$ dan $\mathrm{Cd}$. Oleh karena itu, penelitian ini diadakan untuk mengetahui kadar logam berat $\mathrm{Pb}$ dan $\mathrm{Cd}$ dan hubungan antara sedimen serta kandungan logam berat $\mathrm{Pb}$ dan $\mathrm{Cd}$ dengan komunitas makrozoobentos. Pengambilan sampel dilakukan secara random sampling. PCA (Principle Component Analysis) digunakan untuk mengetahui kedekatan hubungan antara makrozoobentos, nilai bahan organik dan karakteristik sedimen.Perbedaan variabel tiap stasiunnya diuji dengan Uji Kruskal-Wallis. Korelasi Pearson digunakan untuk menganalisis hubungan antara variabel kelimpahan, keanekaragaman, kadar logam berat dan karakteristik sedimen di tiap stasiunnya. Hasil rerata yang diperoleh dari analisa kadar logam berat $(\mathrm{Pb})$ di muara dan sungai Siangker adalah 1,10 - 1,64 mg/l, sedangkan untuk rerata $(\mathrm{Cd})$ sebesar $0,13-0,43 \mathrm{mg} / \mathrm{l}$. Kadar debu mempunyai korelasi positif yang erat $(\mathrm{p}<0,05)$ dengan keanekaragaman dan kelimpahan makrozoobentos. Kadar logam berat berpengaruh nyata $(p<0,05)$ terhadap keanekaragaman maupun kelimpahan makrozoobentos.
\end{abstract}

Kata Kunci : Sungai, logam berat, karakteristik sedimen, makrozoobentos

\section{ABSTRACT}

Siangker river is one of the sub-systems of the West Semarang drainage system that experiencing siltation. Waste from the factories is suspected to contain heavy metals $(\mathrm{Pb})$ and $(\mathrm{Cd})$. This study was conducted to understand concentration of $\mathrm{Pb}$ and $\mathrm{Cd}$ and the relationship between characteristics of the sediments containing heavy metals $(\mathrm{Pb})$ and $(\mathrm{Cd})$ as well as macrozoobenthos community. Sampling was done by random sampling. PCA (Principle Component Analysis) was used to determine proximity of the relationships between macrozoobenthos and the value of organic matter as well as sediment characteristics. Meanwhile, the differences in the station of each variable was tested using Kruskal-Wallis test. Pearson correlation was used to analyze the relationship between abundance variables, diversity, the levels of heavy metals and sediment characteristics in each station. The results showed that the levels of heavy metals $(\mathrm{Pb})$ in the estuary and river Siangker were 1,10 to 1,64 mg / $l$, while concentration of $(C d)$ is 0,13 to $0,43 \mathrm{mg} / \mathrm{l}$. Dust levels were closely positively correlated $(p<0,05)$ with the diversity and abundance of macrozoobenthos. Levels of heavy metals was significant $(p<0,05)$ for the diversity and abundance of macrozoobenthos.

Keywords : River, heavy metal, sediment characteristic, macrozoobenthos

\section{PENDAHULUAN}

Sungai merupakan aliran air yang terbentuk alami di alam yang memiliki pergerakan aliran dari hulu hingga ke hilir. Aliran air yang mengalir menujulautan, danau, samudra maupun bendungan yang melewati muara membawa komponen-komponen sedimen yang ikut serta dalam perjalanan menuju tempatnya.Komponensedimen yang terbawa oleh aliran air akan mengendap di dasar muara. Pengendapan sedimen yang berlangsung terus menerus akan menimbulkan dampak pendangkalan pada daerah muara tersebut. Pendangkalan di muara Sungai Siangker dapat berdampak pada aktivitas jalur pelayaran kapal penangkapan ikan maupun kapal-kapal yang digunakan sebagai alat transportasi masyarakat setempat.Menurut Sudira (2013),

(C) Copyright by Management of Aquatic Resources (MAQUARES) 
proses sedimentasi pada suatu sungai meliputi proses erosi, transportasi, pengendapan dan pemadatan dari sedimentasi itu sendiri.

Polutan logam mencemari lingkungan, baik di lingkungan udara, air dan tanah yang berasal dari proses alami dan kegiatan industri. Proses alami antara lain siklus alamiah sehingga bebatuan gunung berapi bisa memberikan kontribusi ke lingkungan udara, air dan tanah. Kegiatan manusia yang menambah polutan bagi lingkungan berupa kegiatan industri, pertambangan, pembakaran bahan bakar, serta kegiatan domestik lain yang mampu meningkatkan kandungan logam di tanah, udara maupun air. Pencemaran logam, baik dari industri, kegiatan domestik maupun sumber alami akhirnya sampai ke sungai atau laut dan selanjutnya mencemari manusia melalui ikan, air minum, atau air sumber irigasi lahan pertanian sehingga tanaman sebagai sumber pangan manusia tercemar logam (Widowati et al., 2008). Hal ini jika tidak disadari dan di perhatikan akan memberikan dampak buruk bagi ekosistem muara Sungai Siangker dan juga kepada manusia.

Tujuan utama dari penelitian yang dilakukan pada bulan Maret - April 2016 ini adalah untuk mengetahui hubungan antara konsentrasi logam berat dengan sedimen, dan kelimpahan serta keanekaragaman makrozoobentos.

\section{MATERI DAN METODE}

\section{Lokasi Sampling}

Lokasi penelitian berada di bagian sungai hingga muara Siangker.Stasiun I merupakan aliran muara atau hilir Sungai Siangker yang memiliki koordinat $S=6^{\circ} 57^{\prime} 6.68^{\prime}$ ' dan E $=110^{\circ} 22^{\prime} 56.00^{\prime}$ '. Stasiun II merupakan bagian tengah Sungai Siangker yang berada tepat di bawah pembuangan limbah dosmetik yang berasal dari Perumahan Puri Anjasmoro dengan koordinat $\mathrm{S}=6^{\circ} 57^{\prime} 49.65^{\prime}$ ' dan $\mathrm{E}=110^{\circ} 23^{\prime} 1.05$ '. Berikut merupakan gambar peta lokasi penelitiaan.

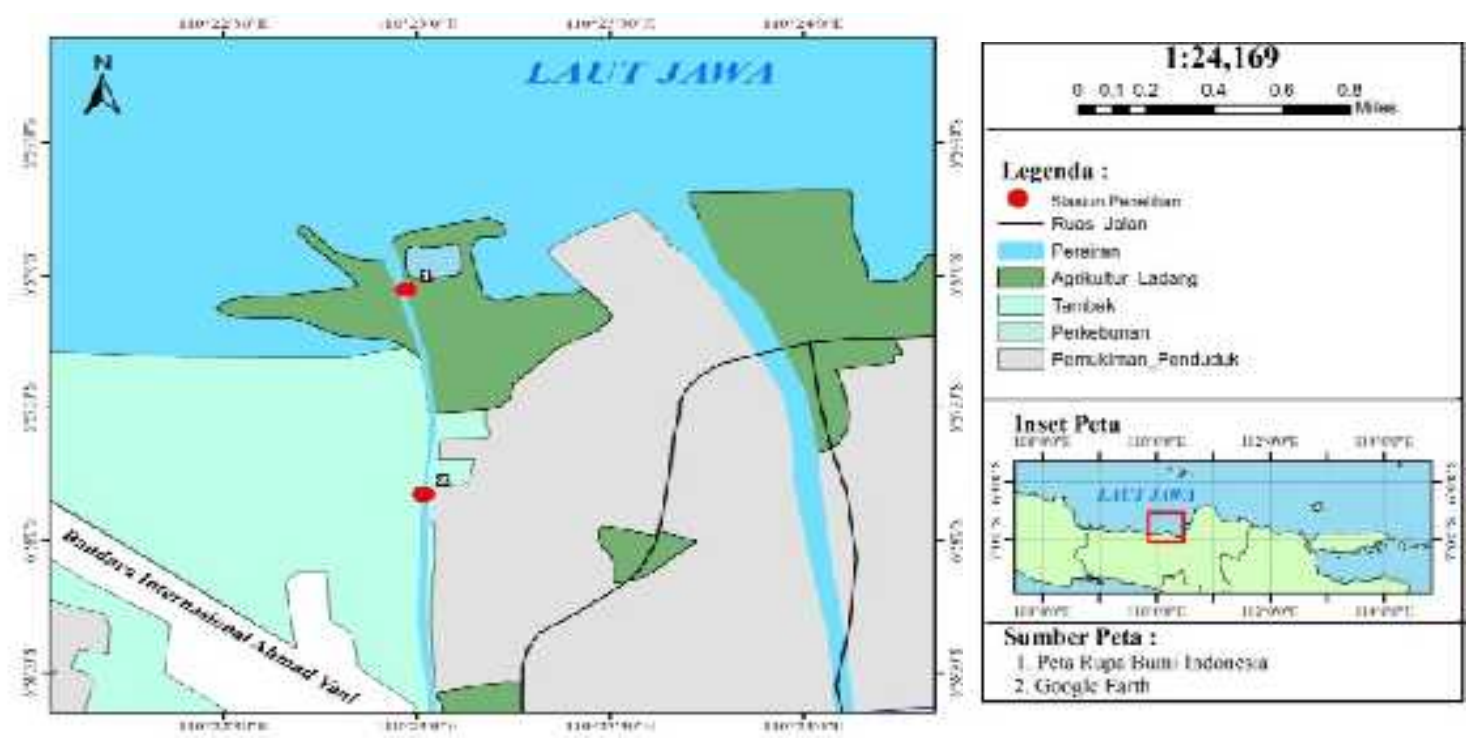

Gambar 1. Lokasi Penelitian

\section{Uji Kandungan Logam Berat timbal (Pb) dan kadmium (Cd)}

Kandunganlogamberat yang diujidalampenelitianiniadalahkandunganlogamtimbal $(\mathrm{Pb})$ dankadmium $(\mathrm{Cd})$. Kadar logamberattimbal $(\mathrm{Pb})$ dankadmium $(\mathrm{Cd})$ diperolehdenganmelakukanujimenggunakanalat AAS (Atomic Absorption Spectroscopy) yang sebelumnyadilakukandestruksibasahdanujianalisalaboratorium yang merujukkepada SNI 6989.46:2009 tentangujitimbal (Pb) dankadmium (Cd) secaraSpektofotometriSerapan Atom (SSA) - tungkukarbon.

\section{UjiAnalisaButiranSedimen}

Sampel yang digunakan untuk menguji butiran sedimen merupakan sedimen yang diambil dari hasil sampling di kedua stasiun penelitian. Sampel sedimen diambil menggunakan Van Veen Grab, sedimen disimpan di plastik dan diberi label yang selanjutnya akan diuji tekstur sedimen.

Uji analisa butiran sedimen merujuk kepada metode menurut (Buchanan, 1971). Metode analisa butiran sedimen pada tahap awalan adalah proses pengovenan sampel sedimen dengan menggunakan oven yang bertemperatur $220{ }^{\circ} \mathrm{C}$ selama \pm 4 . Setelah itu proses selanjutnya adalah penyaringan menggunakan saringan yang memiliki meshize $1 \mathrm{~mm}$, penimbangan sampel sedimen dan pemisahan berdasarkan ukuran butiran sedimen.

$$
\text { (C) Copyright by Management of Aquatic Resources (MAQUARES) }
$$


Tahap selanjutnya adalah metode pemipetan menurut (Buchanan, 1971). Beratsedimen yang telahdidapatkandikonversikandalambentukpersen $(\%)$.

\section{Analisis Makrozoobentos}

Makrozoobentos yang diambil dari kedua stasiun penelitian.Makrozoobentos diambil di tiap stasiun yang masing-masing stasiunnya memiliki 3 titik sampling.Makrozoobentos yang telah didapat setelah itu diawetkan menggunakan formalin $4 \%$ dan diberi Rose Bengal secukupnya sebagai penanda antara serasah dengan makrozoobentos.Makrozoobentos yang didapat setelah itu di hitung kelimpahan dan keanekaragaman individunya.Identifikasi Makrozoobentos dilakukan dengan menggunakan metode checklist yang mengacu pada buku identifikasi FAO 2002.

Analisis Data

Analisis data yang digunakan dalam penelitian ini bertujuan untuk mengetahui hubungan dari sedimen dengan logam berat dan makrozoobentos serta mengetahui kemiripan antara stasiun penelitian sehingga digunakan analisa PCA (Principal Component Analysis), Uji Kruskal-Wallis dan Korelasi Pearson(Zar, 1984).

\section{HASIL DAN PEMBAHASAN}

\section{- Makrozoobentos}

Hasil identifikasi makrozoobentos yang didapatkan di kedua stasiun cukup beranekaragam. Makrozoobentos yang didapat berjumlah 7 buah diantaranya adalah Turitellasp, Terebra sp, Physasp, Onuphidaesp, Nereissp, Perna viridis dan Barbatiasp. Ketujuh makrozoobentos ini memiliki jumlah yang berbeda untuk tiap individu yang ditemukan di kedua stasiun. Ketujuh spesies tersebut dihitung menggunakan rumus kelimpahan dan keanekaragaman untuk mengetahui seberapa padat jumlah spesies yang berada di Staiun I dan II. Hasil kelimpahan makrozoobentos di Stasiun I dan II dapat dilihat di grafik histogram pada Gambar 2

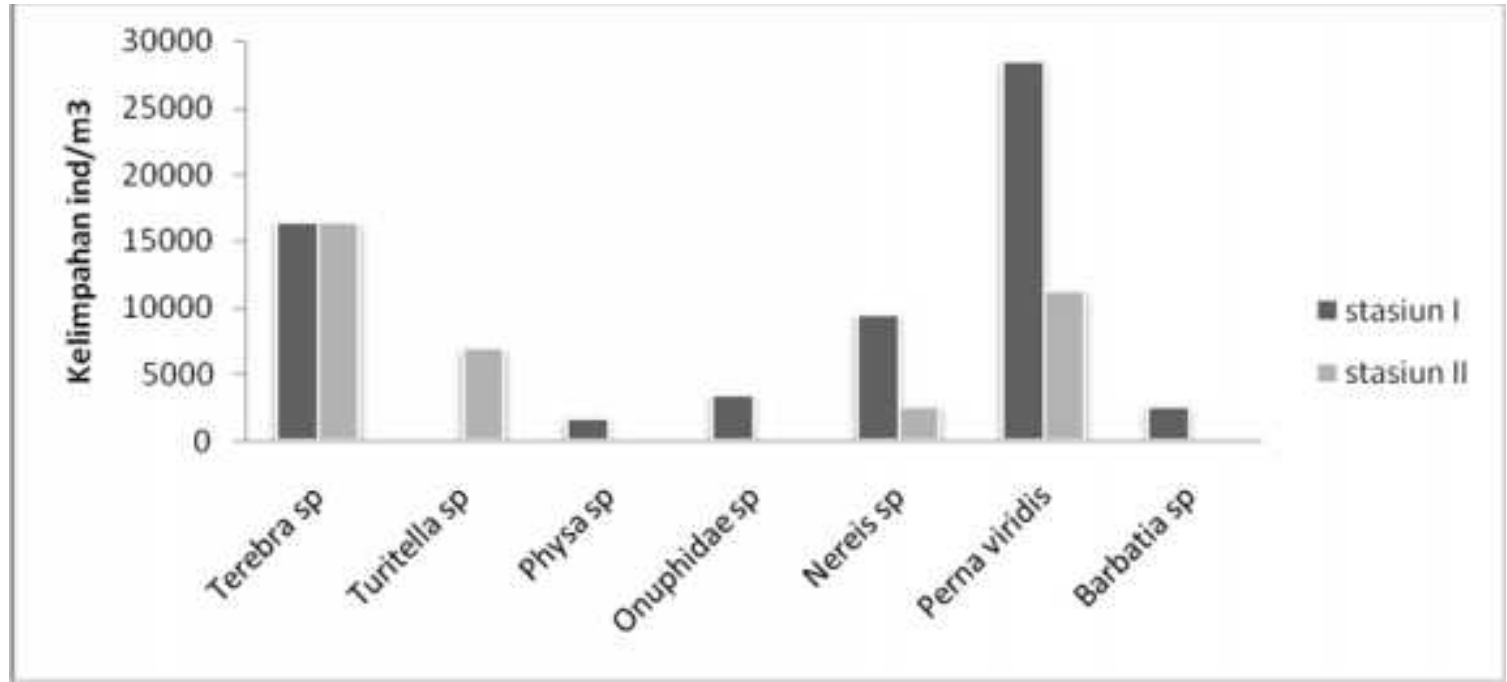

Gambar 2. Kelimpahan Jenis Makrozoobentos (ind $/ \mathrm{m}^{3}$ ) pada tiap stasiun

Berdasarkan Gambar 2. dapat dilihat bahwa nilai kelimpahan makrozoobentos pada pengulangan pertama di Stasiun I dan II memiliki nilai kelimpahan yang paling tinggi dari pada pengulangan kedua, ketiga maupun keempat. Sedangkan untuk keanekaragaman jenis makrozoobentos yang didapat dari hasil sampling, didapatkan bahwa keanekaragaman pada Stasiun I atau Muara Siangker memiliki nilai keanekaragaman yang tinggi dibanding dengan Stasiun II. Jenis makrozoobentos yang didapt di stasiun I juga lebih banyak dibanding Stasiun II. Hal ini dapat disebabkan karena kadar material bahan organik lebih tinggi di Stasiun I dibandingkan dengan Stasiun II.

\section{- $\quad$ Logam Berat Timbal (Pb) dan Kadmium (Cd)}

Hasil analisa uji logam berat timbal $(\mathrm{Pb})$ dan kadmium $(\mathrm{Cd})$ yang dilakukan di kedua stasiun Sungai Siangker dapat dilihat dalam grafik histogram pada Gambar 3. 


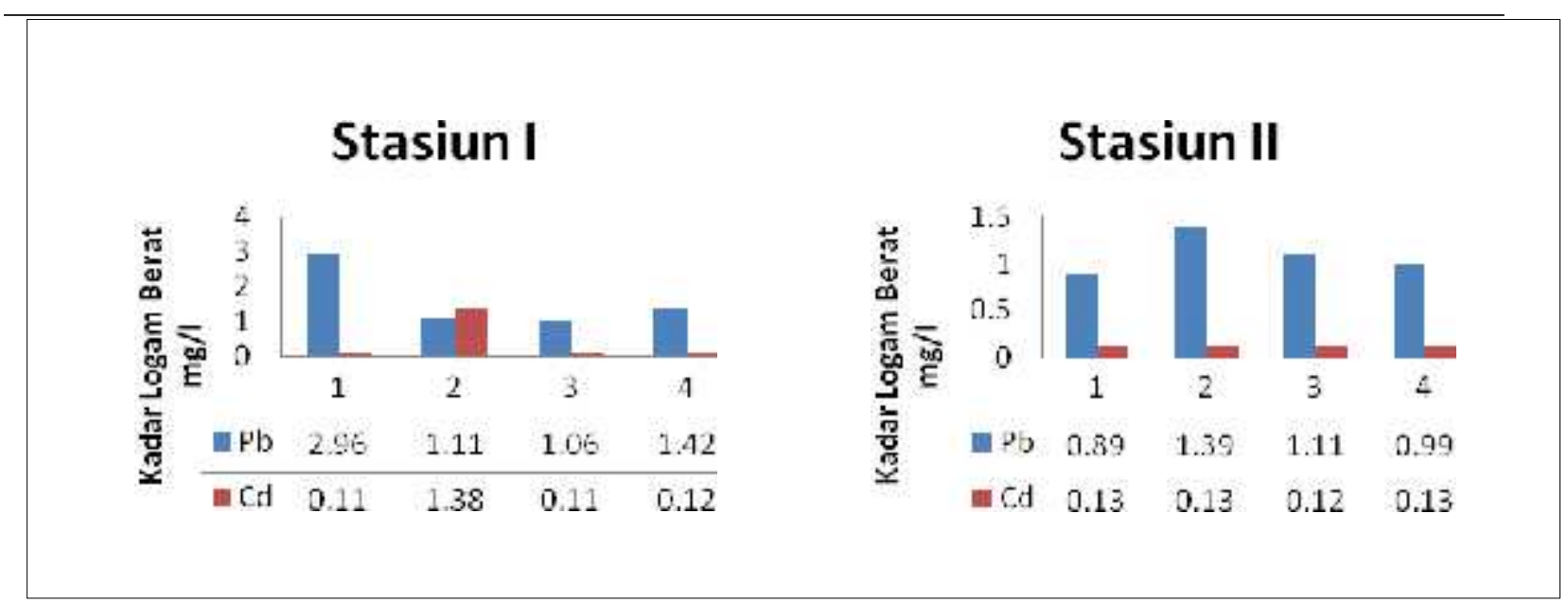

Gambar 3. Diagram Histogram Kadar Logam Berat Timbal (Pb) dan Kadmium (Cd)

Berdasarkan Gambar 3. dapat dilihat bahwa kadar nilai timbal $(\mathrm{Pb})$ di Sungai Siangker baik di stasiun I maupun stasiun II memiliki nilai yang cukup tinggi dibandingkan dengan nilai kadmium (Cd). Hasil rerata yang diperoleh dari nilai logam berat tersebut adalah $0,11-2,96 \mathrm{mg} / \mathrm{l}$ untuk timbal $(\mathrm{Pb})$ dan $0,12-1,39 \mathrm{mg} / \mathrm{l} \mathrm{untuk}$ kadmium $(\mathrm{Cd})$.

\section{- Hubungan Logam Berat dengan Kelimpahan dan Logam Berat dengan Keanekaragaman Makrozoobentos}

Korelasi Pearson digunakan untuk mengetahui berapa besar taraf signifikasi yang dihasilkan antara analisa uji yang diteliti. Analisa yang diuji menggunakan Korelasi Pearson adalah kadar logam berat timbal $(\mathrm{Pb})$ dan kadmium (Cd) dengan kelimpahan dan kadar logam berat timbal $(\mathrm{Pb})$ dan kadmium (Cd) dengan keanekaragaman. Pada analisa uji ini tidak dibandingkan dengan stasiun melainkan hanya perbedaan berdasarkan variabel uji saja. Hasil signifikasi uji Korelasi Pearson dapat dilihat pada Tabel 1.

Tabel 1. Hasil Uji Korelasi Pearson antara Logam Berat dengan Kelimpahan dan keanekaragaman Makrozoobentos

\begin{tabular}{|c|c|c|}
\hline AnalisaUji & $\mathbf{r}$ & Sig. (2-tailed) \\
\hline Logamberattimbal $(\mathrm{Pb})$ dengankelimpahan & 0,575 & 0.136 \\
\hline Logamberatkadmium $(\mathrm{Cd})$ dengankelimpahan & 0,315 & 0.448 \\
\hline Logamberattimbal $(\mathrm{Pb})$ dengankeanekaragaman & 0,037 & 0.931 \\
\hline Logamberat cadmium $(\mathrm{Cd})$ dengankeanekaragaman & 0,844 & $0.009 * *$ \\
\hline
\end{tabular}

**) Nyata pada taraf $0,01 \%$

Berdasarkan Tabel 1bahwa korelasi yang terjadi antara logam berat timbal $(\mathrm{Pb})$ dan kadmium $(\mathrm{Cd})$ dengan kelimpahan makrozoobentos tidak memiliki hubungan yang nyata, karena dapat dilihat pada tabel di atas nilai signifikansi antara ke dua hubungan tersebut adalah $>0,05 \%$, sedangkan untuk korelasi antara logam berat timbal $(\mathrm{Pb})$ dengan keanekaragaman juga belum menyatakan memiliki perbedaan nyata karena nilai $\alpha>0,05 \%$ tetapi berbeda dengan korelasi antara logam berat kadmium dan keanekaragaman. Pada korelasi antara dua variabel ini memiliki perbedaan nyata. Ini dapat dilihat dari nilai $\alpha$ yang dihasilkan dari uji Korelasi Pearson, dengan $\alpha<0,05 \%$ yang berarti antara kadar logam berat kadmium (Cd) memiliki hubungan yang nyata dengan keanekaragaman makrozoobentos.

- Makrozoobentos dengan Logam Berat Timbal (Pb) dan Kadmium (Cd)

Hasil analisa yang didapat dari identifikisai makrozoobentos dan analisa logam berat timbal $(\mathrm{Pb}) \mathrm{dan}$ kadmium (Cd), dengan bahan uji sedimen dan makrozoobentos sebagai biota uji, memiliki hasil rerata 0,11 2,96 mg/l untuk kadar kadmium (Cd) sedangkan untuk rerata nilai kadar timbal $(\mathrm{Pb})$ di Stasiun I dan II sebesar

() Copyright by Management of Aquatic Resources (MAQUARES) 
0,12 - 1,39 mg/l. Nilai kadar logam berat tersebut dihubungkan dengan makrozoobentos yang didapat dari hasil sampling guna untuk melihat pola perseberan antara kadar logam berat dengan makrozoobentos. Hasil Uji PCA hubungan antara kadar logam berat dengan makrozoobentos dapat dilihat pada Gambar 3.

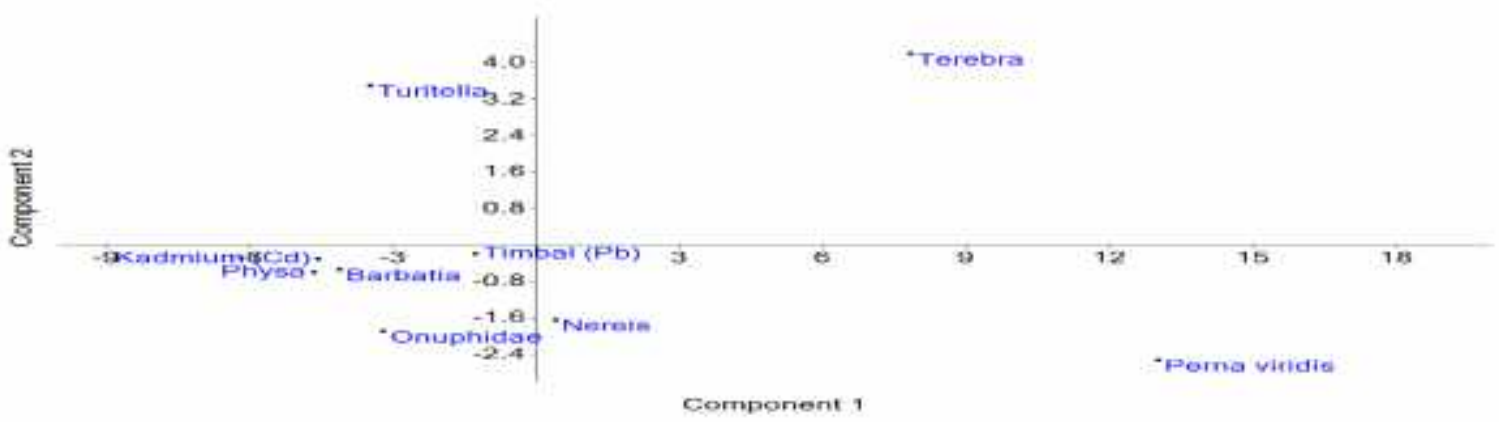

Gambar 4. Hasil Uji PCA Logam Berat dengan Makrozoobentos

Berdasarkan Gambar 4. dapat dilihat bahwa konsentrasi logam berat kadmium (Cd) memiliki nilai signifikasi yang tinggi dengan keberadaan makrozoobentos Physasp, Barbatiasp. Signifikasi antara logam berat kadmium (Cd) dengan Physasp dan Barbatiasp adalah sebesar $\alpha=0,05$. Sedangkan untuk keberadaaan ke lima makrozoobentos lainnya tidak memiliki hubungan langsung dengan kadar logam berat kadmium (Cd) atau dapat dibilang kadar kadmium (Cd) tidak berpengaruh langsung terhadap keberadaan Turitellasp, Onuphidaesp,Nereissp, Terebrasp dan Perna viridis. Kadar logam berat timbal (Pb) pada gambar di atas memiliki signifikasi yang tinggi dengan Onuphidaesp dan Perna viridis. Hubungan kadar logam berat timbal (Pb) dengan kedua makrozoobentos ini memiliki nilai signifikasi sebesar $\alpha=0,05$ untuk nilai signifikasi antara kadar timbal $(\mathrm{Pb})$ dengan Onuphidaesp dan $\alpha=0,01$ untuk nilai signifikasi antara kadar timbal $(\mathrm{Pb})$ dengan Perna viridis.

\section{- Makrozoobentos dengan Butiran Sedimen}

Uji analisa butiran sedimen yang dilakukan di kedua stasiun pada lokasi sampling didapatkan hasil bahwa sifat sedimen yang berada di Sungai Siangker adalah liat. Hal ini dapat disimpulkan karena presentase nilai liat memiliki nilai yang sangat tinggi diantara sifat butiran sedimen pasir dan debu. Nilai maximum presentase liat adalah sebesar 86,88 \%, diikuti dengan nilai maximum presentase pasir sebesar 29,08\% dan debu sebesar $1,40 \%$. Nilai butiran sedimen ini dihubungkan dengan makrozoobentos untuk melihat pola kedekatan persebaran antara butiran sedimen dengan makrozoobentos. Hasil uji PCA butiran sedimen dengan makrozoobentos dapat dilihat pada Gambar 5.

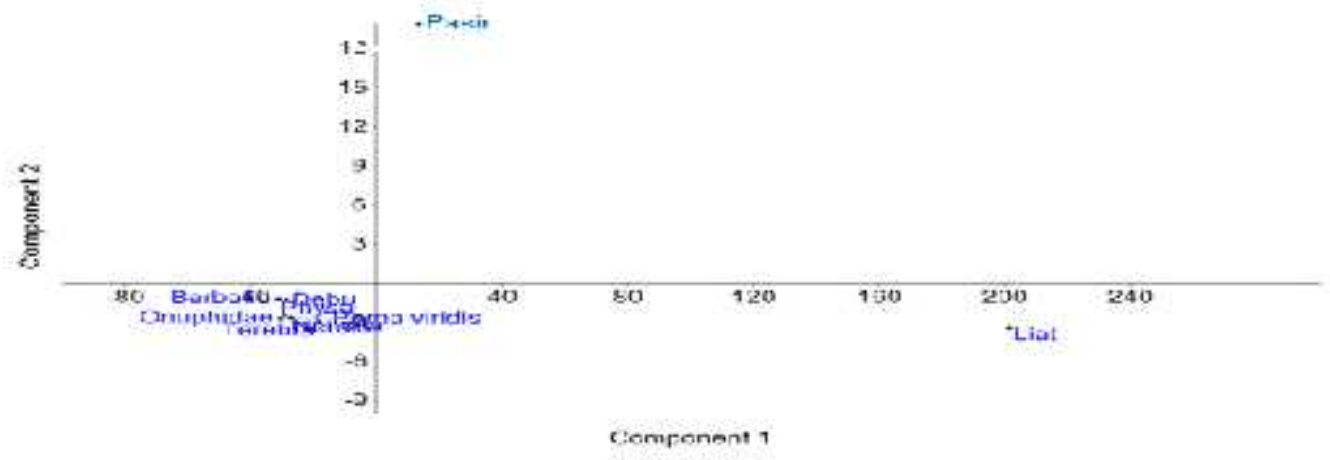

Gambar 5. Hasil Uji PCA Butiran Sedimen dengan Makrozoobentos

Berdasarkan Gambar 5. dapat dilihat bahwa hubungan antara butiran sedimen dengan pola persebaran makrozoobentos sangat mendominasi pada kuadran III. Dimana butiran sedimen debu sangat banyak berdekatan dengan pola persebaran makrozoobentos. Tetapi hanya beberapa spesies saja yang memiliki keterkaitan langsung dengan sifat tanah debu. Makrozoobentos yang memiliki hubungan langsung dengan debu adalah Barbatiasp, Physasp, dan Terebrasp. Sedangkan untuk makrozoobentos yang lain keberadaannya tidak memiliki nilai signifikasi yang tinggi dengan sifat butiran sedimen.

\footnotetext{
${ }^{\circledR}$ Copyright by Management of Aquatic Resources (MAQUARES)
} 


\section{- $\quad$ Perbedaan antara Stasiun Penelitian}

Uji Kruskal-Wallis pada penelitian ini digunakan untuk melihat perbedaan antara hubungan satu variabel dengan variabel lain yang dibedakan dengan melihat nilai perstasiunnya. Nilai Kelimpahan, keanekaragaman, kadar logam timbal $(\mathrm{Pb})$ dan kadmium $(\mathrm{Cd})$ adalah variabel yang diuji menggunakan Uji Kruskal-Wallis ini. Hasil Uji Kruskal-Wallis dengan membandingkan nilai masing-masing variabel uji berdasarkan stasiunnya dapat dilihat pada Tabel 3.

Tabel 3. Hasil Signifikasi Uji Kruskal-Wallis Kelimpahan, Keanekaragaman, Timbal (Pb) dan Kadmium (Cd) dibandingkan berdasarkan Stasiun I dan II.

\begin{tabular}{lr}
\hline \multicolumn{2}{c}{$\begin{array}{c}\text { AnalisaUji } \\
\text { Stasiun I vsStasiun II }\end{array}$} \\
\hline Kelimpahan & Asymp. Sig. \\
Keanekaragaman & $0,056^{*}$ \\
Timbal (Pb) & 0,386 \\
Kadmium (Cd) & 0,191 \\
\hline
\end{tabular}

*) Correlation is significant at the 0,05 level

Berdasarkan hasil tabel di atas dapat diketahui bahwa yang memiliki hubungan antara Stasiun I dan II di masing-masing variabel uji adalah variabel kelimpahan. Pada kelimpahan makrozoobentos didapatkan $\alpha=0,05$ yang artinya bahwa nilai kelimpahan makrozoobentos pada Stasiun I memiliki perbedaan nyata dengan Stasiun II. Sedangkan untuk nilai keanekaragaman makrozoobentos, kadar timbal $(\mathrm{Pb})$ dan kadmium $(\mathrm{Cd})$ antar stasiunnya tidak memiliki perbedaan nyata karena nilai $\alpha$ pada masing-masing analisa uji menunjukkan $\alpha>0,05$.

\section{PEMBAHASAN}

Sungai (run-off river) adalah jalur masuk bahan pencemar yang kemudian mengontaminasi laut. Bahan pencemar dapat masuk secara langsung ke sungai melalui saluran-saluran pembuangan (sewer) daerah pemukiman, limpasan permukaan (surface run-off) dari kegiatan pertanian, konstruksi jalan bangunan dan pelabuhan. Dalam beberapa kondisi buangan limbah industri digelontorkan langsung ke lingkungan laut atau melalui jalur klasik yakni sungai berupa bahan berbahaya dan beracun (B3). Limbah B3 yang dibuang melalui sungai kemudian akan mencapai lautan. Hujan akan memberikan kontribusi masuknya bahan pencemar (75\% berupa bahan kimia beracun, misalnya logam berat) ke lingkungan laut melalui sungai (Syakti et al., 2012). Kadar logam berat timbal $(\mathrm{Pb})$ dan kadmium $(\mathrm{Cd})$ yang berada di sungai hingga muara Siangker masih menunjukkan angka yang aman bagi keadaan lingkungan sungai dan muara tersebut. Kadar logam berat yang didapatkan adalah sebesar 0,11 - 2,96 mg/l untuk kadar logam timbal $(\mathrm{Pb})$ dan 0,12 - 1,39 mg/luntuk kadar logam kadmium (Cd). Nilai konsentrasi logam berat di sedimen dapat melebihi6.000 mg/kg (ppm) di lokasilokasi yang dekat dengan tambang logam, sementara residu di sedimen dari sumber industri dan urban tidak melebihi 500 ppm. Konsentrasi Pb di sedimen bervariasi tergantung dengan keadaan lokasi (Syakti et al., 2012).

Menurut Arifin (2001) dalam Haeruddin (2006), mendeteksi bahwa konsentrasi timbal dalam sedimen di perairan pesisir Jakarta mendekati $120 \mathrm{mg} / \mathrm{kg}$, Surabaya sekitar $60-70 \mathrm{mg} / \mathrm{kg}$. Pekan baru sekitar $50-60 \mathrm{mg} / \mathrm{kg}$ dan Semarang sekitar $30 \mathrm{mg} / \mathrm{kg}$. SedimentasikonsentrasilogamKadmium (Cd) dalam sedimen tertinggi di Semarang (> $5 \mathrm{mg} / \mathrm{kg}$ ), Jakarta (> $3 \mathrm{mg} / \mathrm{kg}$ ), Surabaya $(>2.5 \mathrm{mg} / \mathrm{kg}$ ) danPekanbaru (>0.1 mg/kg). Konsentrasi alami logam Pbdan Cd dalam sedimen masing-masing adalahsebesar $20 \mathrm{mg} / \mathrm{kg}$ dan $0.15 \mathrm{mg} / \mathrm{kg}$.Keberadaan kadmium (Cd) sendiri di alam akan tinggi apabila nilai pH pada lingkungan tersebut sangat tinggi atau dikatagorikan sebagai basa. Karena kadmium akan mengalami presipitasi atau pengendapan di lingkungan tersebut. Kadmium juga bersifat akumulatif dan sangat toksik bagi organisme (Syakti et al., 2012).

Kadar kadmium (Cd) yang berada di kedua staisun memiliki nilai yang rendah, hal ini dapat disebabkan sumber pencemaran yang masuk ke dalam Sungai Siangker masih pada taraf yang kecil. Menurut Muller et al., (1979) dalamPalar (2008), bahwakonsentrasi Cd yang berasal dari limbah cair rumah tangga sebesar 5\% dari jumlah kandungan Cd yang lainnya.

Tidak hanya kadmium $(\mathrm{Cd})$, pada logam berat timbal $(\mathrm{Pb})$ juga berhubungan dengan $\mathrm{pH}$ sedimen atau dengan $\mathrm{pH}$ lingkungannya. Kadar logam berat ini akan tinggi mengendap pada sedimen jika $\mathrm{pH}$ tersebut bersifat asam dan tanah yang berada di lingkungan tersebut bersifat asam humik. Pada $\mathrm{pH}$ rendah kedua logam berat tersebut tidak terlalu tinggi dan juga pada tanah yang bersifat lempung (clay) (Syakti, 2012).

Berdasarkanuji PCA yang telah dilakukan bahwa tekstur sedimen dan spesies makrozoobentos memiliki keterkaitan langsung. Jenis tekstur sedimen mempengaruhi pola penyebaran makrozoobentos di daerah sungai. Menurut Odum (1993) dalam Riniatsih dan Kushartono (2009), bermacam-macam jenis dari substrat sangat penting dalam perkembangan komunitas makrozoobentos, pasir cenderung memudahkan untuk bergeser dan 
bergerak ketempat lainnya. Substrat berupa lumpur biasanya mengandung sedikit oksigen, oleh karena itu organisme yang hidup di dalamnya harus dapat beradaptasi pada keadaan ini. Substrat lumpur sangat berpengaruh terhadap kehidupan makrozoobentos dibandingkan dengan substrat berpasir.

Nilai kelimpahan dan keanekaragaman makrozoobentos yang didapatkan antara tiap stasiun memiliki perbedaan. Perbedaan nilai tersebut dipengaruhi oleh nilai bahan organik yang terdapat di masing-masing stasiun dan juga jenis substrat yang berada di sungai tersebut. Nybakken (1988)dalam Mentari et al., (2015)yang menyatakan bahwa adanya substrat dasar yang berbeda-beda menyebabkan perbedaan fauna atau struktur komunitas makrozoobentos. Jenis makrozoobentos yang sering didapatkan pada saat sampling lapangan adalah kelas polychaeta dan bivalve. Polychaeta banyak ditemukan di daerah muara dengan jenis substrat yang lebih berpasir dibanding dengan substrat yang berada di tengah sungai. Gholizadeh et al., (2012)dalam Mentari et al., (2015) , menyatakan bahwa tekstur sedimen lumpur banyak ditemukan makrozoobentos kelas polychaeta, sedangkan pada substrat pasir banyak ditemukan kelas gastropoda.

Makrozoobentos yang didapatkan pada kedua stasiun berjumlah 7 spesies. Beberapa makrozoobentos tersebut memiliki nilai signifikasi tinggi, ini berarti antara makrozoobentos dengan logam berat timbal dan kadmium memiliki hubungan yang nyata. Makrozoobentos yang memiliki hubungan langsung dengan logam timbal adalah Perna viridis dan Onuphidaesp. Sedangkan untuk Barbatiaspdan Physasp memiliki hubungan langsung dengan logam berat kadmium. Menurut Wardhana (2001), Hubungan konsentrasi logamberat kadmium (Cd) dengan keberadaan biota di perairan. Konsentrasi Cd di perairan dalam badan perairan dalam konsentrasi tertentu dapa tmembunuh biota perairan seperti crustacea, bangsa insecta, keluarga oligochaeta dan ikan mas untuk biota yang ada di air tawar. Syamsurisal (2011), keanekaragaman mencakup dua hal penting yaitu banyaknya jenis, sehingga semakin kecil jumlah jenis dan variasi individu tiap jenis memiliki penyebaran yang tidak merata, maka keanekaragaman akan mengecil.

\section{KESIMPULAN}

Kesimpulan yang diperoleh dari penelitian ini adalah sebagai berikut:

Hasil rerata yang didapat dari pengujian kadar logam berat di muara dan sungai Siangker untuk $(\mathrm{Pb})$ adalah $1.10 \mathrm{mg} / \mathrm{l}-1.64 \mathrm{mg} / \mathrm{l}$, sedangkan untuk nilai $(\mathrm{Cd})$ sebesar $0.13 \mathrm{mg} / \mathrm{l}-0.43 \mathrm{mg} / \mathrm{l}$. Nilai konsentrasi ini dikategorikan rendah bagi pencemaran lingkungan, serta hubungan butiran sedimen dengan keanekaragaman dan kelimpahan makrozoobentos menghasilkan korelasi positif untuk kadar debu, sedangakan hubungan kadar logam berat dengan keanekaragaman dan kelimpahan makrozoobentos memiliki perbedaan nyata dengan $\alpha<0,05$.

\section{UCAPAN TERIMAKASIH}

Penulis mengucapkan terimakasih kepada Prof. Dr. Ir. Djoko Suprapto, DEA, Dr. Ir. Max R. Muskananfola, M.Sc dan Dr. Ir. Frida Purwanti, M.Sc dan Dr. Ir. Pujiono Wahyu Purnomo, M.S atas segala kritik dan saran yang diberikan dalam hasil penelitian ini serta semua pihak yang telah membantu dalam penyususnan skripsi ini.

\section{DAFTAR PUSTAKA}

Buchanan, J.B. 1971. Sediment Analysis.In Holme and McLntryre.Method for Study of Marine Benthos.Blackhel Scientific Publication. London.

FAO. 2002. FAO Species Identification Guide for Fishery Purposes: The Living Marine Resources of The Western Central Pacific. Volume 3,4,5, dan 6. FAO, Rome

Haeruddin. 2006. Analisis Terpadu Sedimen dalam Penetapan Status Pencemaran Perairan Estuari Wakak Plumbin Kabupaten Kendal, Jawa Tengah. [Disertasi].Sekolah Pascasarjana. Institut Pertanian Bogor, Bogor.

Mentari, L ., Ruswahyuni dan M. R. Muskananfola. 2015. Distribusi Kelimpahan Makrozoobentos dan Kandungan Bahan Organik serta Tekstur Sedimen pada Muara Sungai Wakak, Kabupaten Kendal. Fakultas Perikanan dan Ilmu Kelautan, Universitas Diponegoro. Semarang.Maquares., 4(4): 19 - 23

Odum, E. P. 1971. Fundamental Of Ecology. Third Edition. W.B. Saunders Company: Philadelphia.

Palar, H. 2008. Pencemaran dan Toksikologi Logam Berat. Rineka Cipta, Jakarta.

Purnawan, S., I. Setiawan dan Marwantim. 2012. Studi Sebaran Sedimen Berdasarkan Ukuran Butir Di Perairan Kuala Gigieng, Kabupaten Aceh Besar, Provinsi Aceh. Jurusan Ilmu Kelautan, Koordinator Kelautan dan Perikanan, Universitas Syiah Kuala. [Jurnal], Banda Aceh

Riniatsih, I dan E. W. Kushartono. 2009. Substrat Dasar dan Parameter Oseanografi sebagai Penentu Keberadaan Gastropoda dan Bivalvia di Pantai Sluke Kabupaten Rembang. Semarang. 
Sudira, I. W. 2013. Analisis Angkutan Sedimen pada Sungai Mansahan. Luwuk.

Syakti, A. D., N. V. Hidayati dan A. S. Siregar. 2012. Agen Pencemaran Laut. IPB Press. Kampus IPB Taman Kencana Bogor, Bogor.

Syamsurisal. 2011. Studi Beberapa Indeks Komunitas Makrozoobentos di Hutan Mangrove Kelurahan Coppo Kabupaten Barru. [Skripsi].Universitas Hasanuddin, Makassar.

Wardhana, W. A. 2001. Dampak Pencemaran Lingkungan. Andi Yogyakarta. Yogyakarta.

Widowati, W., A. Sastiono dan R. J. Rumampuk. 2008. Efek Toksik Logam (Pencegahan dan Penanggulangan Pencemaran). Andi Yogyakarta. Yogyakarta.

Zar, J. H. 19841. Biostatistical Analysis.Prentice-Hall. International, Inc. Unites States America, America. Finglewood Cliffs, New Jersey. 